\title{
MICROSTRUCTURAL EVOLUTION OF THE NORMALIZING PLATE ROLLING OF NIOBIUM MICROALLOYED STEELS
}

\author{
Antonio Augusto Gorni ' \\ Marcos Roberto Soares da Silva ${ }^{2}$
}

\begin{abstract}
There are concerns about the use of $\mathrm{Nb}$ microalloyed steels in the normalizing rolling of plate steels, as this thermomechanical treatment is finished at a temperature range where $\mathrm{Nb}(\mathrm{CN})$ precipitation can promote partial recrystallization of austenite. The aim of this work was to verify the effectiveness of $\mathrm{Nb}$ in retarding austenite recrystallization and to determine conditions under which $\mathrm{Nb}$ microalloyed steels can be processed through normalizing rolling fulfilling, as much as possible, the metallurgical recommendations proposed to this thermomechanical treatment, mainly the full austenite recrystallization between consecutive rolling passes.
\end{abstract}

Keywords: Normalizing rolling; Nb microalloyed steel; Austenite recrystallization; Precipitation.

\section{EVOLUÇÃO MICROESTRUTURAL NA LAMINAÇÃO DE NORMALIZAÇÃO DE CHAPAS GROSSAS DE AÇOS MICROLIGADOS AO NIÓBIO}

\section{Resumo}

O uso de aços microligados ao Nb na laminação de normalização de chapas grossas traz algumas preocupações devido ao fato desse tratamento termomecânico terminar sob temperaturas em que uma eventual precipitação de $\mathrm{Nb}(\mathrm{CN})$ pode levar à recristalização parcial da austenita. $\mathrm{O}$ objetivo deste trabalho foi verificar até que ponto o Nb efetivamente atrasa a recristalização da austenita e determinar as condições em que se obedece ao máximo às recomendações metalúrgicas propostas para a laminação de normalização, particularmente a necessidade de recristalização total da austenita entre passes consecutivos.

Palavras-chave: Laminação de normalização; Aço microligado ao nióbio; Recristalização da austenita; Precipitação.

\section{INTRODUCTION}

Some grades of structural steel plate are supplied in the normalized condition. In this case, the rolled product is austenitized in a furnace and then allowed to cool in still air. However, the continuous need for process rationalization and cost reduction paved the way for the production of normalized plates directly from the rolling heat. This is possible through the use of a thermomechanical treatment called normalizing rolling, a variant of the recrystallization controlled rolling. The ideal normalizing rolling process is characterized by full recrystallization between hot rolling passes and a finishing temperature that is equal to the austenitizing temperature originally used in the heat treating furnace. The final aim is a ferrite-pearlite microstructure with fine and homogeneous grain size.

Of course the quality of furnace normalized plates is better than those produced through normalizing rolling [I]. The conventional normalized plate is submitted to re-austenitization and subsequent slow cooling, an additional heat treatment which contributes to minimize central segregation and to refine microstructure. Besides that, a correctly re-austenitized steel plate shows no temperature gradient when it leaves the austenitizing furnace. Of course, the normalized rolled plate lacks this additional treatment. Besides that, it intrinsically will show a temperature gradient along thickness in the end of the hot rolling process, as this process requires several minutes to be completed. As these drawbacks do not affect seriously product quality, many standards accept this alternative route since plate thickness does not exceed 40 $\mathrm{mm}$. However, normalized rolled plates must show limited alterations on their mechanical properties after an additional normalizing heat treatment - say, a maximum loss of 50 to $60 \mathrm{MPa}$ in yield strength [2].

This process route was firstly designed at the Cubatão works of Usiminas in the late 1990's, defining then the use of

'Hot Rolling, Usiminas-Cubatão, Cubatão, SP, Brazil.E-mail: antonio.gorni@usiminas.com

${ }^{2}$ Hot Rolling Technical Support Group, Usiminas-Cubatão, Cubatão, SP, Brazil. E-mail: marcos.silva@usiminas.com 
$\mathrm{Ti}$ and TiV microalloyed steels for plates produced according to the DIN $17100 \mathrm{St} 52.3 \mathrm{~N}$ standard [3]. While titanium contributes to grain refining, vanadium grants mechanical strength if the normalized rolled plate is submitted to an additional normalizing heat treatment, as it re-solubilizes during austenitizing and re-precipitates during cooling in still air.

However, as Brazil has to import vanadium and is plenty of niobium, local steelworks prefer to use $\mathrm{Nb}$ microalloyed grades for normalized plates, including those ones processed directly from the rolling heat [4]. While this approach is fully satisfactory in the case of heat treated plates, some questions must be addressed when the normalizing rolling route is to be used. First of all, as the finishing rolling temperature of this process is generally around $900^{\circ} \mathrm{C}$, plates will be partially rolled in a "forbidden" temperature range, where $\mathrm{NbCN}$ precipitation is not able to suppress full austenite recrystallization between rolling passes, but prevents its completion. This range roughly extends from $1,025^{\circ} \mathrm{C}$ to $900^{\circ} \mathrm{C}$. This partial recrystallization of austenite significantly affects microstructure homogeneity, with a potential negative effect over plate toughness.

Another point to be considered is the contribution to steel strength due to the interphase niobium precipitation that develops during plate cooling in still air after rolling. This contribution will be lost if the normalized rolled plate is to be submitted to an additional normalizing treatment in the customer. Unlike vanadium, niobium precipitates do not solubilize as the plate is reheated during the normalizing heat treatment, as commercial austenitizing temperature (say, $900^{\circ} \mathrm{C}-920^{\circ} \mathrm{C}$ ) normally is far lower than $\mathrm{NbCN}$ solubilization temperature (between $1,150^{\circ} \mathrm{C}-\mathrm{I}, 250^{\circ} \mathrm{C}$ ). So interphase precipitates grow during plate re-austenitization and lose their hardening effect. Eventually the loss in mechanical strength can be greater than the limits specified by the quality standards [2].

The aim of this work is to analyze, with greater detail, the interaction between niobium precipitation and the kinetics of austenite recrystallization, as well the resulting microstructure evolution, considering a typical normalizing rolling of a microalloyed steel performed in an industrial plate mill. It is expected that this analysis can reveal better process conditions which can satisfy the metallurgical requirements of the normalizing rolling process.

\section{MATERIALS AND METHODS}

First of all, it was necessary to define a typical plate mill pass schedule applied in normalizing rolling to be considered in the calculations of microstructural evolution. The default plate rolling process condition chosen for this work considered the case of a $16 \mathrm{~mm}$ thick final plate produced from a $260 \mathrm{~mm}$ thick slab rolled in 20 passes down to a finishing temperature of $885^{\circ} \mathrm{C}$. It was also assumed that the initial austenite grain size after slab reheating was $150 \mu \mathrm{m}$, a typical value for $\mathrm{Nb}$ microalloyed steels. Pass schedule data included roll gap, work roll peripheral speed, plate temperature and time between consecutive passes. It also included an intermediate holding phase, which time length was specifically designed to promote final rolling under the specified finishing temperature. The default chemical composition of steel, expressed in weight percent, is $0.05 \% \mathrm{C}, 1.25 \% \mathrm{Mn}, 0.35 \% \mathrm{Si}$ and $0.0085 \% \mathrm{~N}$.

The microstructural evolution model was programmed in Excel using the Visual Basic for Applications language [5]. It is mainly based in the work by Dutta and Sellars [6], Valdes and Sellars [7] and Liu et al. [8], which describe the fundamental equations used to calculate $5 \%$ and $95 \%$ austenite recrystallization kinetics, $5 \% \mathrm{NbCN}$ precipitation kinetics and the resulting austenite grain size. The amount of solute $\mathrm{Nb}$ was calculated according to the Irvine equation [9].

\section{RESULTS AND DISCUSSION}

The first thing to do was to determine the microstructural evolution of a plain C-Mn steel submitted to the normalizing rolling process, a case where there is no restriction of austenite recrystallization due to precipitation effects. The results generated by this model are shown in Figure I, considering the default steel and an initial austenite grain size equal to $300 \mu \mathrm{m}$, a value typical for plain C-Mn steels after slab reheating. Surprisingly, the model showed that full austenite recrystallization occurred only in five passes. This makes clear that the inherent limitations of industrial rolling prevent full application of the ideal metallurgical directives. Strain per pass must be limited in the beginning of plate rolling due to roll bite limitations and the high loads typical of the broadsizing phase (transversal rolling). But much serious is the restriction of strain per pass in the last three passes, which must be observed to preserve plate flatness. The predicted final mean austenite grain size, as shown in Figure 2, is about $23 \mu \mathrm{m}$ but, unfortunately, the model is not able to predict its dispersion. So, it can be concluded that

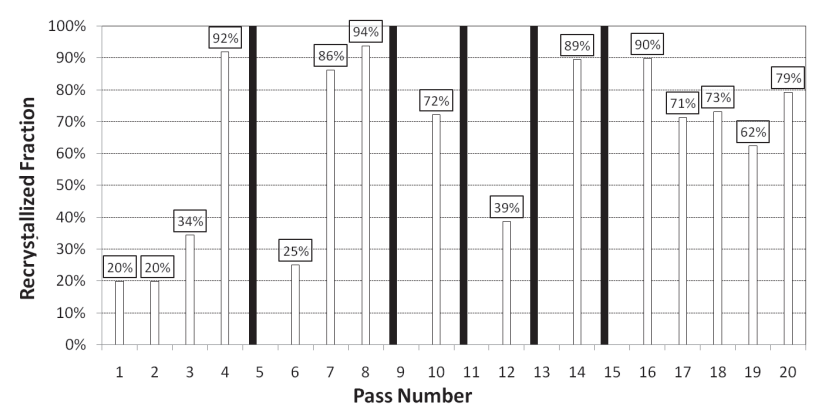

Figure I. Prediction of the recrystallized fraction between consecutive passes during normalizing rolling of a C-Mn steel according to the default pass schedule described here. 
the proposed normalizing rolling conditions are not ideal even for C-Mn steels, where austenite recrystallization is not hindered by $\mathrm{NbCN}$ precipitation.

The next step was to determine the occurrence of $\mathrm{NbCN}$ precipitation during normalizing rolling of a microalloyed steel as a function of $\mathrm{C}$ and $\mathrm{Nb}$ contents of steel. Considering the default pass schedule and steel composition (with $0.05 \% \mathrm{C}$ ), the model showed that $\mathrm{Nb}$ precipitation during austenite recrystallization only occurs after the last pass if $\mathrm{Nb}$ contents are equal or over $0.020 \%$. However, for a $0.10 \% \mathrm{C}$ steel, this happens for steels with at least $0.018 \% \mathrm{Nb}$; for a $0.15 \% \mathrm{C}$, this value decreases to $0.013 \%$. The model also predicted that a rise of finishing temperature from $885^{\circ} \mathrm{C}$ to $920^{\circ} \mathrm{C}$ will allow the use of greater $\mathrm{Nb}$ contents without the occurrence of precipitation. In this case, for a $0.05 \% \mathrm{C}$ steel, precipitation after the last pass will require a minimum of $0.036 \% \mathrm{Nb}$; this value is equal to $0.022 \% \mathrm{Nb}$ in the case of a $0.10 \% \mathrm{C}$ steel and $0.016 \% \mathrm{Nb}$ for a $0.15 \%$ steel.

Of course, greater amounts of $\mathrm{N}$ favored $\mathrm{NbCN}$ precipitation but, under industrial conditions, this effect is very discrete. For example, considering a $0.05 \% \mathrm{C}$ steel with $0.030 \% \mathrm{Nb}$, finishing temperature of $885^{\circ} \mathrm{C}$ and $0.0005 \% \mathrm{~N}$, $\mathrm{Nb}$ precipitation occurred during austenite recrystallization only after the last pass. The increase of $\mathrm{N}$ to $0.0120 \%$ only promoted precipitation during austenite recrystallization in the two last passes.

Recrystallization kinetics can be accelerated through the use of heavier rolling passes. So an alternative pass schedule was proposed, with an increase of $20 \%$ in the strain applied in each pass, except the initial passes down to the end of the broadsizing step (due to the already mentioned bite problems and excessive rolling loads) and the last three passes (due to flatness control). Consequently, the number of passes decreased from 20 to 16. A steel with $0.15 \% \mathrm{C}$ and $0.015 \% \mathrm{Nb}$ was considered in this specific case; all other variables were equal to the default plate rolling process. Figure 3 shows a graphic with the curves for $5 \%$ and $95 \%$ austenite recrystallization and $5 \% \mathrm{NbCN}$ precipitation considering the default pass schedule, while Figure 4 shows the same curve, but for the heavier pass schedule. A comparison between these two figures shows clearly that heavier passes accelerated both recrystallization and precipitation kinetics, but the effect over recrystallization is stronger. However, as strain in the last three passes could not be increased due to flatness concerns, recrystallization kinetics remained the same, while precipitation was accelerated. While precipitation affected only austenite kinetics in the two last passes of the default pass schedule, in the heavier one austenite kinetics was affected in the last three passes.

These results clearly show that heavier passes are favorable for austenite recrystallization kinetics, but this is useless (or even harmful) if the last passes could not be heavier. An option here is to adopt roll bending or other mechanical devices that increase pass schedule flexibility while promoting good plate flatness. If this approach is not feasible, eventually flatness could be sacrificed at the plate mill exit, but immediately recovered using more intensively the hot leveller.

Figure 5 shows the recrystallized fraction between passes during a typical normalizing rolling of a $0.15 \% \mathrm{C}$ steel with $0.020 \% \mathrm{Nb}$ using the default pass schedule described in

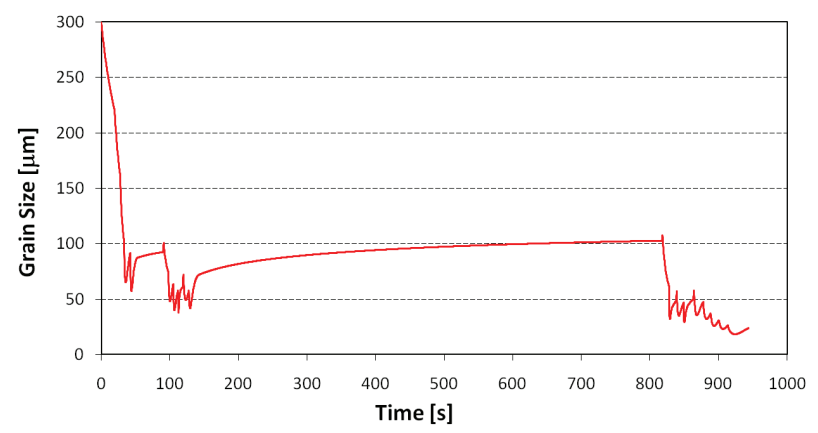

Figure 2. Grain size evolution predicted during normalizing rolling of a C-Mn steel according to the default pass schedule described here.

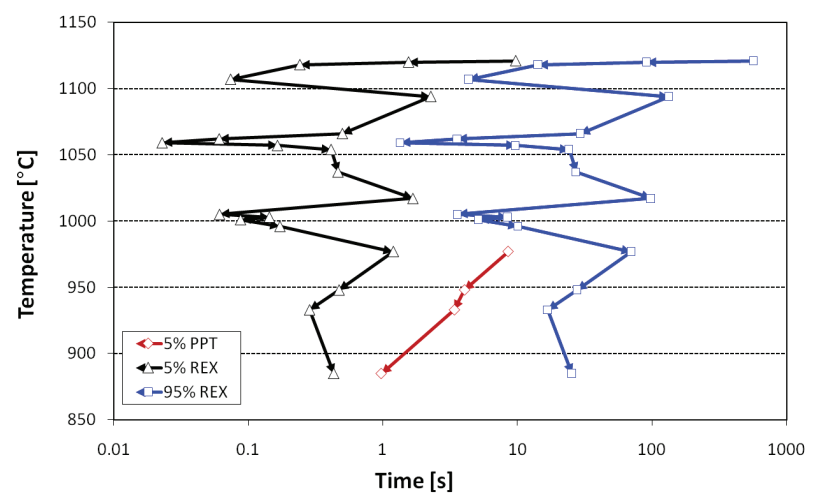

Figure 3. Curves for $5 \%$ and $95 \%$ austenite recrystallization and $5 \% \mathrm{NbCN}$ precipitation determined by the Dutta-Valdes-Sellars-Liu model for a steel with $0.15 \% \mathrm{C}$ and $0.015 \% \mathrm{Nb}$ processed according to the default pass schedule.

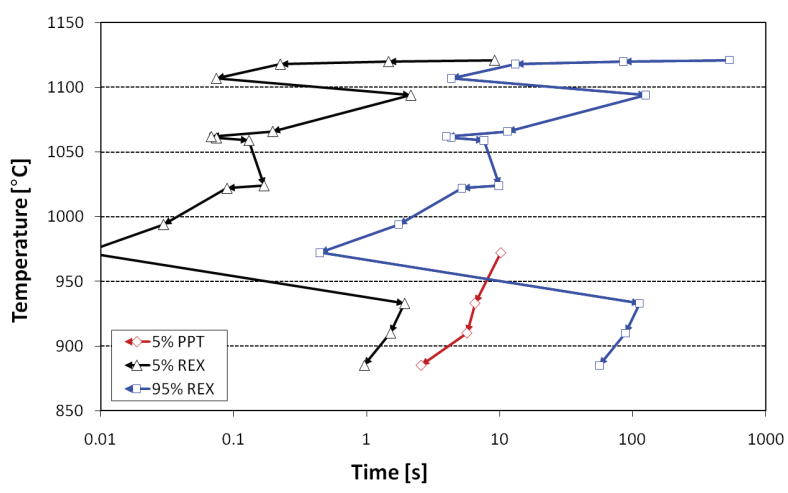

Figure 4. Curves for $5 \%$ and $95 \%$ austenite recrystallization and $5 \% \mathrm{NbCN}$ precipitation determined by the Dutta-Valdes-Sellars-Liu model for a steel with $0.15 \% \mathrm{C}$ and $0.015 \% \mathrm{Nb}$ processed according to the heavier pass schedule. 
this paper. It is interesting to note that the model predicted that full recrystallization will occur in eight passes, more than the five observed in the C-Mn steel processed under the same conditions. Although austenite recrystallization kinetics is slower in $\mathrm{Nb}$ microalloyed steels, higher strain accumulation from previous passes and finer grain size accelerate recrystallization kinetics. But, in the end of plate rolling, as temperature and strain per pass falls, austenite kinetics is more sluggish in the $\mathrm{Nb}$ steel than in plain $\mathrm{C}-\mathrm{Mn}$

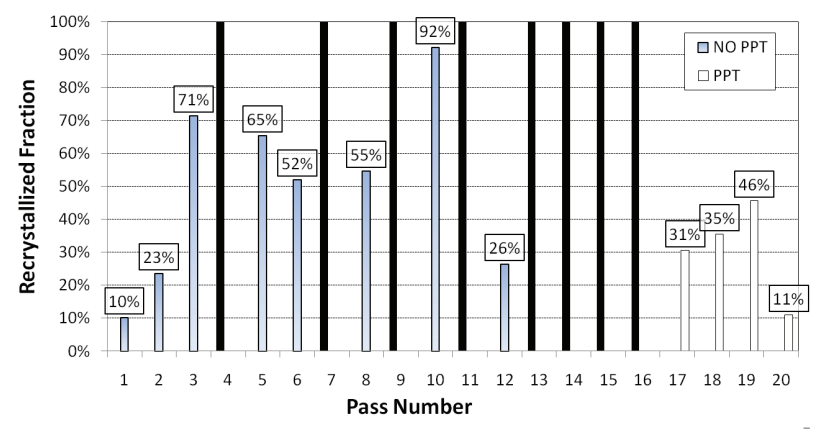

Figure 5. Recrystallized fraction predicted between passes during the normalizing rolling of a $0.15 \% \mathrm{C}, 0.020 \% \mathrm{Nb}$ and $0.0085 \% \mathrm{~N}$ steel according to the default pass schedule described in this work.

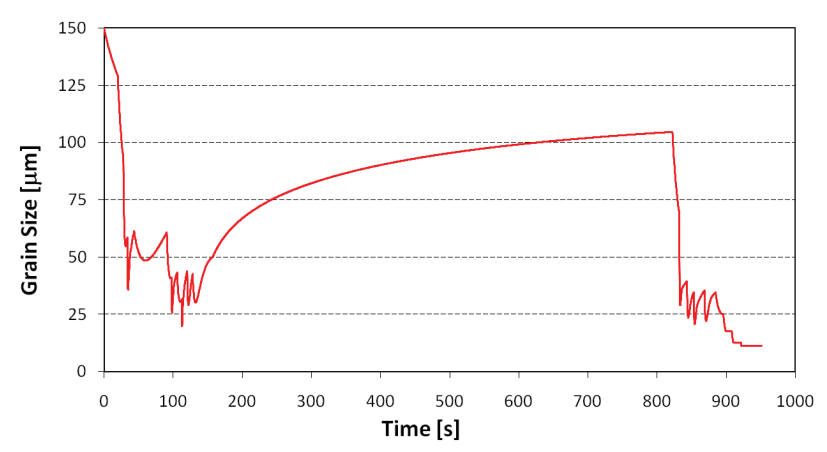

Figure 6. Grain size evolution predicted during normalizing rolling of a $0.15 \% \mathrm{C}, 0.020 \% \mathrm{Nb}$ and $0.0085 \% \mathrm{~N}$ steel according to the default pass schedule described here.

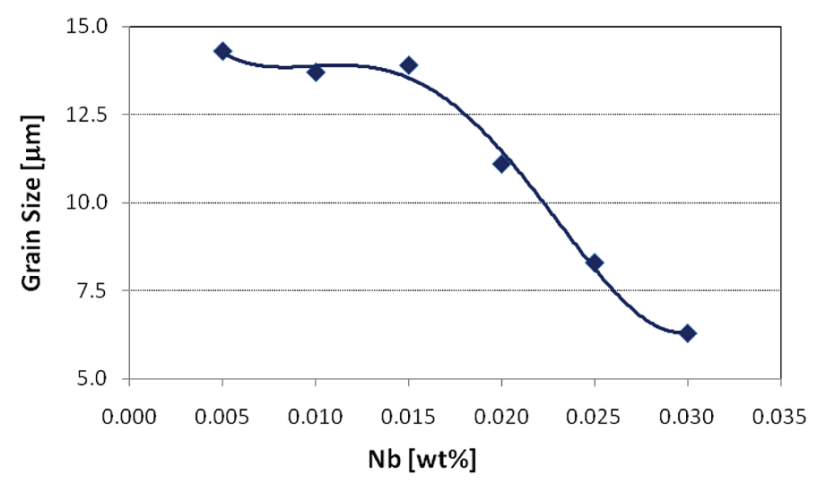

Figure 7. Austenite mean grain size at end of normalizing rolling in function of $\mathrm{Nb}$ content for a $0.15 \% \mathrm{C}$ steel, according to the default pass schedule described in this work. steel. Comparing the results got in the last five passes considering the C-Mn (Figure I) and $\mathrm{Nb}$ (Figure 5) steels, the recrystallized fractions were $90 \% / 100 \%, 71 \% / 31 \%$, $73 \% / 35 \%, 62 / 46 \%$ and $79 \% / 11 \%$. According to Figure 6 , the predicted final mean grain size after normalizing rolling of the $\mathrm{Nb}$ microalloyed steel is about I I $\mu \mathrm{m}$, less than the half of the value got for the C-Mn steel. The lower mean grain size in the $\mathrm{Nb}$ microalloyed steel will contribute to greater levels of mechanical strength and toughness compared to the C-Mn steel, but the sluggish austenite recrystallization between passes can promote a higher level of microstructure heterogeneity that can be detrimental to toughness.

An analysis about the mean austenite grain size got immediately after normalizing rolling showed that their values were in the range between $12 \mu \mathrm{m}$ and $15 \mu \mathrm{m}$ for the $0.05 \%$ and $0.10 \% \mathrm{C}$ steels; the influence of $\mathrm{Nb}$ content was not significant. However, for a $0.15 \% \mathrm{C}$ steel, grain size significantly changes if $\mathrm{Nb}$ content is greater than $0.015 \%$, as can be seen in Figure 7. In such condition, interaction between austenite recrystallization and $\mathrm{NbCN}$ precipitation is more frequent, leading to a greater grain refining.

\section{CONCLUSIONS}

Due to operational reasons, industrial normalizing rolling does not always follow strictly the metallurgical directives recommended for the production of a product with high strength, toughness and homogeneity. An aspect specially disregarded is the need of thickness reductions of at least 15\% per pass in order to promote full austenite recrystallization between passes. This situation applies not only to the C-Mn steels processed by this route, but particularly for $\mathrm{Nb}$ microalloyed steels, where austenite recrystallization is strongly retarded by $\mathrm{Nb}$ in solution and totally suppressed as $\mathrm{NbCN}$ precipitation begins. So, in order to get best results with $\mathrm{Nb}$ microalloyed steel processed through normalizing rolling, it is recommended to minimize $\mathrm{C}$ and $\mathrm{Nb}$ contents of steel and to increase finish temperature and strain per pass, as these measures retard $\mathrm{NbCN}$ precipitation and promote austenite recrystallization. The decrease of $\mathrm{N}$ content is also beneficial, although its effect over $\mathrm{NbCN}$ precipitation is secondary. Although is very difficult to apply high strains in the last three passes of plate rolling, this is highly recommended, as final plate microstructure is being defined at this moment. Eventually flatness problems resulting from high strains in such passes can be remediated by resources like roll bending or a more intense application of hot levelling after plate rolling. Final grain size got after normalizing rolling shows little variation, oscillating in the range between $12 \mu \mathrm{m}$ and $15 \mu \mathrm{m}$, except for steels with $\mathrm{C}$ and $\mathrm{Nb}$ contents higher than $0.15 \%$ and $0.015 \%$, respectively, where a strong microstructure refinement happens. 


\section{REFERENCES}

I Taylor K, Bodnar R, Nelson T, Jansto S, Tsosie H, Hu Z, et al. Evaluation of low- and medium-C Nb-microalloyed plate steels for wind tower applications. Iron \& Steel Technology. 20I I;8(I0): I 27-I 40.

2 zur Begutachtung von Erzeugnissen V. (Band, Blech, Breitflachstahl), die mit geregelter Temperaturführung beim und nach dem Walzen hergestellt werden, zum Nachweis der Gleichwertigkeit mit dem Normalglühen. VdTÜV; 1976. Merkblatt Werkstoffe, no. 1263.4 p.

3 Gorni AA, Cavalcanti CG, Reis JSS, Silveira JHD, Silva CNP. Laminação de normalização para produção de chapas grossas grau DIN 17100 52.3N. In: Associação Brasileira de Metalurgia, Materiais e Mineração. Anais do $53^{\circ}$ Congresso Anual da ABM; 1998 Set. I7; Belo Horizonte, Brasil. São Paulo: ABM; 1998. p. 850-864.

4 Diniz PP. O processo de laminação de normalização nas propriedades mecânicas de chapas grossas estruturais de aço carbono-manganês microligados ao nióbio e titânio [monografia]. São Paulo: Escola Politécnica, USP; 2008.

5 Gorni AA. Cálculo da temperatura de não-recristalização para aços microligados, em função da interação entre a precipitação e a recristalização da austenita. REM: Revista Escola de Minas. 1999;52(I):2 I-25.

6 Dutta B, Sellars CM. Effect of composition and process variables on $\mathrm{Nb}(\mathrm{C}, \mathrm{N})$ precipitation in $\mathrm{Nb}$ microalloyed austenite. Materials Science and Technology. 1987;3(3): 197-206. http://dx.doi.org/I0.I I79/mst. 1987.3.3. 197.

7 Valdes $\mathrm{E}$, Sellars $\mathrm{CM}$. Influence of roughing rolling passes on kinetics of strain induced precipitation of $\mathrm{Nb}(\mathrm{C}, \mathrm{N})$. Materials Science and Technology. 1991;7(7):622-630. http://dx.doi.org/10.1 I79/mst. 1991.7.7.622.

8 Liu X, Solberg JK, Gjengedal R, Kluken AO. Modelling of interaction between recrystallization and precipitation during multipass rolling of niobium microalloyed steels. Materials Science and Technology. 1995; I (5):469-473. http://dx.doi.org/10.1 179/mst.1995.11.5.469.

9 Irvine KJ, Pickering FB, Gladman T. Grain Refined C-Mn Steels. Journal of the Iron and Steel Institute. 1967;205:161182.

Received: 10 Mar. 2014

Accepted: 4 Feb. 2015 